\title{
Oral Hairy Leukoplakia as Prediction Oral Lesion for HIV Disease : A Review Article
}

\author{
Nanda Rachmad Putra Gofur ${ }^{1 *}$, Aisyah Rachmadani Putri Gofur ${ }^{2}$, Soesilaningtyas ${ }^{3}$, Rizki Nur Rachman Putra \\ Gofur $^{4}$, Mega Kahdina ${ }^{4}$ and Hernalia Martadila Putri ${ }^{4}$ \\ ${ }^{1}$ Department of Health, Faculty of Vocational Studies, Universitas Airlangga, Indonesia
}

${ }^{2}$ Faculty of Dental Medicine, Universitas Airlangga, Indonesia

${ }^{3}$ Department of Dental Nursing, Poltekkes Kemenkes, Indonesia

${ }^{4}$ Faculty of Medicine, Universitas Airlangga, Indonesia

*Corresponding author: Nanda Rachmad Putra Gofur, Department of Health, Faculty of Vocational Studies, Universitas Airlangga, Surabaya, Indonesia

\begin{abstract}
Introduction: Oral Hairy Leukoplakia (OHL) is a hyperplastic mucocutaneous epithelial cell disease, induced by Epstein Barr virus (EBV). The clinical appearance of OHL is as white, corrugated, painless, and asymptomatic lesion, as a patch that cannot be removed by scrapping, located often bilaterally on lateral borders of the tongue. The prevalence of OHL was reported to be $20 \%$ in asymptomatic HIV infection in the United States to 36\% with Acquired Immunodeficiency Syndrome (AIDS). Worldwide 2006, the prevalence of OHL in Brazil was 28,8\%, also reported a prevalence of $38.8 \%$ and $21,8 \%$ in northern and southern USA.

Discussion: Oral hairy leukoplakia is a specific lesion in HIV infection caused by Epstein Barr virus, and has been reported in over more than $28 \%$ patients and is a sign of disease progression. OHL appear clinically as an asymptomatic, white, or grayish white, well demarcated plaque with corrugated texture [1]. The "hairy" surface varies in size from a few millimeters to extensive lingual and oral mucosal involvement. These lesion typically occurs on the lateral tongue but may also appear on the ventral and dorsal surface of the tongue, and more rarely, on the buccal mucosa.

Conclusion: The establishment of Oral Hairy Leukoplakia as a diagnosis have a diagnostic value for HIV infection. Oral manifestations are the earliest and most important indicators of HIV infection. OHL is often wrongly diagnosed and thus proper treatment is delayed. The present of OHL in the absence of known cause of immunosuppression strongly suggest HIV infection. In the early diagnosis of OHL, health care provider must be cautious and seek further examination to establish HIV infection.
\end{abstract}

Keywords: OHL; infection; HIV; oral lesion

Abbreviations: OHL: Oral Hairy Leukoplakia; EBV: Epstein Barr Virus; AIDS: Acquired Immunodeficiency Syndrome

\section{Introduction}

Oral Hairy Leukoplakia (OHL) is a hyperplastic mucocutaneous epithelial cell disease, induced by Epstein Barr virus (EBV), and it is the first pathologic manifestation attributable to replicative EBV infection [1]. The clinical appearance of OHL is as white, corrugated, painless, and asymptomatic lesion, as a patch that cannot be removed by scrapping, located often bilaterally on lateral borders of the tongue [2]. In the prevalence of OHL was reported to be $20 \%$ in asymptomatic HIV infection in the United States to $36 \%$ with Acquired Immunodeficiency Syndrome (AIDS) [3]. Worldwide 2006, the prevalence of OHL in Brazil was 28,8\% [4]. Another study reported a prevalence of $38.8 \%$ in Thailand [5]. Reported prevalence rates in OHL vary considerably according to the clinical criteria used and the characteristic of the study population, such as the type of immunosuppression and clinical stage of the patients. EpsteinBarr virus is a human herpesvirus that is associated with important human diseases, including infectious mononucleosis syndrome, malignant lymphoma, and nasopharyngeal carcinoma. In adults 
worldwide, the serologic prevalence of EBV estimated around 95\%. Latently infected, circulating B-lymphocytes are believed to be a site of lifelong EBV persistence. The productive replications of EBV occur in the surfaces of the oral mucosa and sheds infectious, transmissible virus into the saliva [6]. HIV infections represent a spectrum disease that can begin with a brief acute retroviral syndrome that typically transitions to a multiyear chronic and clinically latent illness. Without treatment, this illness eventually progresses to a symptomatic, life threatening immunodeficiency disease known as AIDS. OHL has been associated with more rapid progression to AIDS among HIV viral-infected individuals, and with HIV viral loads exceeding 20.000 copies/ml, and with CD4+ counts below $200 / \mathrm{mm}[7,8]$. OHL is a disease of minimal morbidity that does not always require intervention. This is due to the fact that OHL is a benign, asymptomatic, and potentially self-limiting lesion. Therapy is indicated when symptoms become troubling or when there is a need for cosmetic reasons [9].

\section{Discussion}

\section{Oral hairy leukoplakia}

Oral hairy leukoplakia is a specific lesion in HIV infection caused by Epstein Barr virus, and has been reported in over more than $28 \%$ patients and is a sign of disease progression [10]. OHL appear clinically as an asymptomatic, white, or grayish white, well demarcated plaque with corrugated texture [11]. The "hairy" surface varies in size from a few millimeters to extensive lingual and oral mucosal involvement [12]. These lesion typically occurs on the lateral tongue but may also appear on the ventral and dorsal surface of the tongue, and more rarely, on the buccal mucosa [13]. The characteristic appearance of OHL is caused by hypertrophy of the involved lingual papillae. In general, the lesion is painless and irremovable by blunt manipulation [13]. When the lesion became symptomatic, it may represent superimposed or coinfection with candidiasis [14]. OHL is a benign lesion characterized by abundant EBV productive replication. EBV (or also called human herpesvirus 4) is from the gamma subfamily of Herpesviridae [14-16]. The virus remains in lifelong latency by residing in circulatory memory B lymphocytes of the peripheral blood, which serve as the cellular reservoir of persistent latent EBV infection $[17,18]$. The virus is transmitted by means of mucosal excretions, for example, saliva, through shedding of EBV-infected oropharyngeal cells during viral reactivation [19]. It remains unclear whether EBV derives from reactivation of latent strains in the tongue epithelium or is acquired through contact with EBV-infected saliva or through EBV-positive circulating B lymphocytes [18]. Recent studies have shown that infected monocytes, macrophages, or Langerhans cells of the peripheral blood migrate through lamina propria into oral epithelium and infect terminally differentiated cells of the upper portion of the spinous layer, initiating productive viral replication and EBV dissemination $[20,21]$. These cells could be the source of reactivation for EBV productive replication [8,20,22].

\section{OHL as prediction lesion in HIV disease}

Severe immunosuppression can lead into reactivation of EBV replication in the oropharynx of EBV-seropositive patients. EBV replication has also been found in normal oral epithelium, this suggest that replication alone is insufficient for the pathogenesis of OHL and that cofactors are required [23]. The lateral border of the tongue is the most common location of OHL. The development of OHL on the tongue may be related to the accumulation of saliva in the floor of the mouth and the resting position of the tongue in a pool of EBV-shedding saliva [4]. Other explanation is the decreased number of Langerhans cells in OHL lesions when compared with nonregional oral mucosa. A comparative study of normal mucosa revealed that the lowest density of Langerhans cells was found on the lateral border of the tongue and the sublingual region. Thus, normal epithelium of the lateral and ventral sides of the tongue is more susceptible to EBV infection [23]. The importance of OHL as an indicator of immunosuppression was recognized soon after it was first described, when the authors observed that a proportion of the patients developed AIDS-defining illness within a relatively short time following the diagnosis of OHL [3,24,25]. In 1992 the European Economic Community published a revised classification of oral lesion associated with HIV infection in adults [26], where OHL is one of the lesions strongly associated with HIV infection as can be seen in Table 1 [27]. The findings of OHL in patients who are tested positive for HIV infection can give some predictive immune system condition of how progressive the infection is, as it is believed to have correlation with CD4 $\mathrm{T}$ cell counts. The rare occurrence of OHL in healthy individuals and the association of OHL in HIVpositive patients with low CD4+ T Cells Count and high viral load suggests a role of stimulation of EBV by HIV or a distinct role of CD4 $\mathrm{T}$ cells in protection against disease (Table 2). 
Table 1: WHO Clinical Staging of HIV/AIDS for Adults and Adolescents [27].

\begin{tabular}{|c|c|c|}
\hline Primary HIV Infection & Clinical Stage 1 & Clinical Stage 2 \\
\hline $\begin{array}{l}\text { a) Asymptomatic } \\
\text { b) Acute retroviral syndrome }\end{array}$ & $\begin{array}{l}\text { a. Asymptomatic } \\
\text { b. Persistent generalized } \\
\text { lymphadenopathy }\end{array}$ & $\begin{array}{l}\text { i. Moderate unexplained weight loss ( }<10 \% \text { of presumed or } \\
\text { measured body weight) } \\
\text { ii. Recurrent respiratory infections (sinusitis, tonsillitis, otitis } \\
\text { media, and pharyngitis) } \\
\text { iii. Herpes zoster } \\
\text { iv. Angular cheilitis } \\
\text { v. Recurrent oral ulceration } \\
\text { vi. Papular pruritic eruptions } \\
\text { vii. Seborrheic dermatitis } \\
\text { viii. Fungal nail infections } \\
\text { ix. Fungal nail infections }\end{array}$ \\
\hline Clinical Stage 3 & & Clinical Stage 4 \\
\hline $\begin{array}{l}\text { A. Unexplained severe weight loss ( }>10 \% \text { of presumed } \\
\text { or measured body weight) } \\
\text { B. Unexplained chronic diarrhea for }>1 \text { month } \\
\text { C. Unexplained persistent fever for }>1 \text { month ( }>37.6^{\circ} \mathrm{C} \text {, } \\
\text { intermittent or constant) } \\
\text { D. Persistent oral candidiasis (thrush) } \\
\text { E. Oral hairy leukoplakia } \\
\text { F. Pulmonary tuberculosis (current) } \\
\text { G. Severe presumed bacterial infections (e.g., pneu- } \\
\text { monia, empyema, pyomyositis, bone or joint infection, } \\
\text { meningitis, bacteremia) } \\
\text { H. Acute necrotizing ulcerative stomatitis, gingivitis, or } \\
\text { periodontitis Unexplained anemia (hemoglobin }<8 \text { g/ } \\
\text { dL) } \\
\text { I. Neutropenia (neutrophils }<500 \text { cells } / \mu \mathrm{L} \text { ) } \\
\text { J. Chronic thrombocytopenia (platelets }<50,000 \text { cells/ } \\
\mu \text { L) }\end{array}$ & & $\begin{array}{l}\text { a) HIV wasting syndrome, as defined by the CDC. } \\
\text { b) Pneumocystis pneumonia } \\
\text { c) Recurrent severe bacterial pneumonia } \\
\text { d) Chronic herpes simplex infection (orolabial, genital, or } \\
\text { anorectal site for }>1 \text { month or visceral herpes at any site) } \\
\text { e) Esophageal candidiasis (or candidiasis of trachea, bronchi, or } \\
\text { lungs) } \\
\text { f) Extrapulmonary tuberculosis } \\
\text { g) Kaposi sarcoma } \\
\text { h) Cytomegalovirus infection (retinitis or infection of other } \\
\text { organs) } \\
\text { i) Central nervous system toxoplasmosis } \\
\text { j) HIV encephalopathy } \\
\text { k) Cryptococcosis, extrapulmonary (including meningitis) } \\
\text { l) Disseminated nontuberculosis mycobacteria infection. } \\
\text { m) Progressive multifocal leukoencephalopathy } \\
\text { n) Candida of the trachea, bronchi, or lungs } \\
\text { o) Chronic cryptosporidiosis (with diarrhea) } \\
\text { p) Chronic isosporiasis } \\
\text { q) Disseminated mycosis (e.g., histoplasmosis, coccidioidomyco- } \\
\text { sis, penicilliosis) } \\
\text { r) Lymphoma (cerebral or B-cell non-Hodgkin) } \\
\text { s) Invasive cervical carcinoma } \\
\text { t) Atypical disseminated leishmaniasis } \\
\text { u) Symptomatic HIV-associated nephropathy } \\
\text { v) Symptomatic HIV-associated cardiomyopathy } \\
\text { w) Reactivation of American trypanosomiasis (meningoenceph- } \\
\text { alitis or myocarditis) }\end{array}$ \\
\hline
\end{tabular}

Table 2: Staging of HIV Infection Based on CD4 Cells Count and Percentage [26].

\begin{tabular}{|c|c|c|}
\hline CD4 Cells $/ \boldsymbol{\mu L}$, Absolute Count & CD4\% & Staging for Adults \\
\hline$>600$ & $32-50$ & Normal \\
\hline$<500$ & $<29$ & Initial Immune Suppression \\
\hline$<400$ & $<29$ & Oral lesions may appear \\
\hline $200-400$ & $14-28$ & Increased severity and number of opportunistic infections and oral lesions \\
\hline$<200$ & $<14$ & AIDS, severe immune suppression \\
\hline
\end{tabular}




\section{Clinical manifestation of OHL}

Clinical findings are usually enough to be a presumptive diagnose in patients with HIV infection. A further definitive criterion when necessary must be demonstrated by the presence of EBV in the lesions to be determined by histopathology, exfoliative cytology, in situ hybridization, or PCR [28]. Histopathologically, epithelial hyperplasia, hyper and parakeratosis, and ballooning, vacuolated, koilocytic epithelial cells with minimal or no surrounding inflammation [29], and also nuclei that have a ground-glass appearance and nuclear beading can be found in OHL. Exfoliative cytopathology of OHL revealed features of Cowdry type A inclusion bodies, ground glass nuclei, and nuclear beading. If the facilities to demonstrate the presence of EBV are not available, a lack of response to antifungal treatment or a demonstration of an immunodeficient status can reinforce the presumptive diagnose [30] (Figure 1).
The differential diagnosis of OHL includes cancer or carcinoma in situ, hypertrophic candidiasis, lichen planus, hyperkeratotic leukoplakia [14] and frictional keratosis [4]. A complete history and physical examination and supported by further additional examination could help differentiate the diagnose. A propose to do a biopsy to determine the histopathology nature of the lesion was refused by the patient due to its invasiveness. PCR and in situ hybridization cannot be performed due to the lack of facilities. A cytopathology examination by scrapping of the lateral border of the tongue was performed. The scrapping was done by a cytobrush and directly smeared onto the glass slides, fixed in alcohol, and was then stained by the standard Papanicolau stain. The result of the cytopathology examination was smear consists of squamous epithelial, mononuclear inflammation cells and a cluster of coccus and hyphae also present. No sign of dysplasia and malignancy. The conclusion is a microorganism infection.

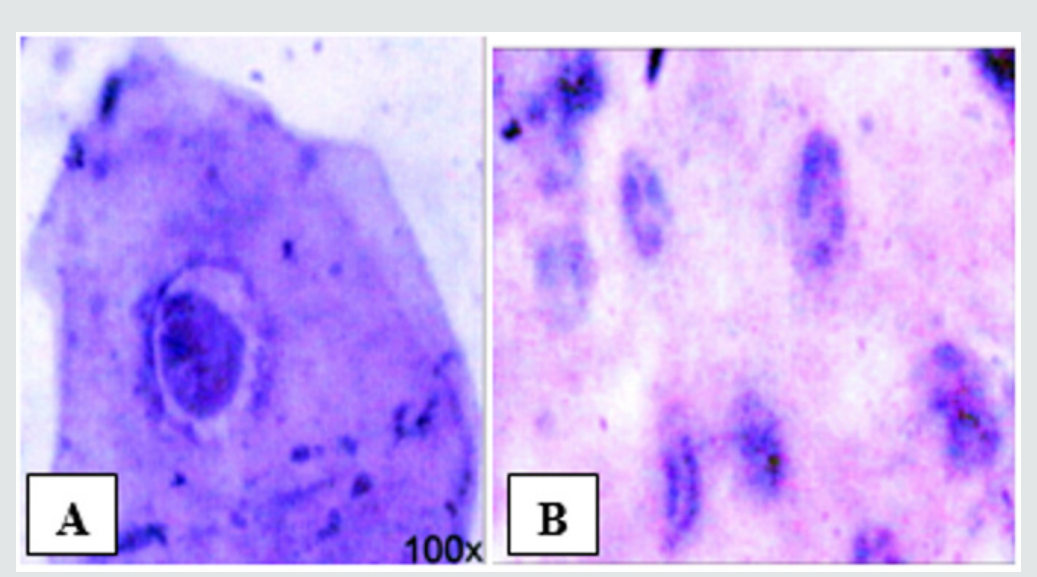

Figure 1: (A) Cowdry type A inclusion bodies along with perinuclear halo (B) Glass appearance of the nucleus and a peripheral nuclear beading, both (A) and (B) are PAP-stained, 100x magnification [30].

\section{Treatment of $\mathrm{OHL}$}

Treatments for OHL when required consist of varying options. Usually, the institution of HAART with reduced viral load and increased CD4 count help a significant reduction in the prevalence of OHL patients. Systemic antiherpesviral therapy produces rapid resolution, although sometimes the recurrence can be expected when therapy is discontinued. Systemic antiherpesviral therapies known to be used are acyclovir and valacyclovir, with several reports the use of desiclovir and famciclovir. Acyclovir is a nucleoside analog available in the form of oral, intravenous, and topical. The triphosphate form of the drug is the active form, which has a potent inhibitory effect on herpesvirus-induced DNA polymerases but relatively little effect on host cell DNA polymerase [31]. In OHL, acyclovir effectively resolves the permissive infection, although cessation of treatment often results in a recurrence of lesions within 1-4 months [14,31].

\section{Conclusion}

The establishment of Oral Hairy Leukoplakia as a diagnosis have a diagnostic value for HIV infection. Oral manifestations are the earliest and most important indicators of HIV infection. OHL is often wrongly diagnosed and thus proper treatment is delayed. The present of OHL in the absence of known cause of immunosuppression strongly suggest HIV infection. In the early diagnosis of OHL, health care provider must be cautious and seek further examination to establish HIV infection. Institution of HAART after the diagnosis of HIV infection could induce the resolution of OHL. Other treatments such as systemic antiherpesviral accelerate the resolution process. The ability to recognize early OHL manifestation in patient with HIV is key to providing optimal and appropriate care, give early medical intervention and thus prolonging patient's life and revise its quality. 


\section{Conflict of Interest}

None

\section{Funding}

None

\section{References}

1. Radwan Ozcko M, Mendak M (2011) Differential diagnosis of oral leukoplakia and lichen planus - on the basis of literature and own observations. J Stoma 5(6): 355-370.

2. Sixbey JW (2008) Epstein-Barr Virus Infection. Holmes KK, Sparling PF, Stamm WE, Piot P, Wasserheit JN, Corey L, et al. (Eds.), Sexually Transmitted Disease. $4^{\text {th }}$ Ed, McGraw Hill, New York, USA pp. 453-59.

3. Moura MDG, Grossman SMC, Foncesca LMS, Senna MIB, Mesquita RA (2010) Risk factors for oral hairy leukoplakia in HIV-infected adults of Brazil. J Oral Pathol Med 35: 321-326.

4. Walling MD, Flaitz CM, Nichols CM (2003) Epstein-Barr virus replication in oral hairy leukoplakia : response, persistence, and resistance to treatment with valacyclovir. J Infect Dis 188: 883-890.

5. Triantos D, Porter SR, Scully C, Teo CG (1997) Oral hairy leukoplakia: clinicopathologic features, pathogenesis, diagnosis, and clinical significance. Clin Infect Dis 25: 1392-1396.

6. Greenspan D, Greenspan J (1992) Significance of oral hairy leukoplakia. Oral Surg Oral Med Oral path 73: 151-154.

7. Kerdpon D, Pongsiriwet S, Pangsomboon K (2004) Oral manifestations of HIV infection in relation to clinical and CD4 immunological status in northern and southern Thai patients. Oral Dis 10: 138-144.

8. Uihlein LC, Saavedra AP, Johnson RA (2011) Cutaneous manifestations of human immunodeficiency virus disease. Goldsmith LA, Katz SI, Gilchrest BA, Paller AS, Leffell DJ, et al. (Eds.), Fitzpatrick's Dermatology in General Medicine. $8^{\text {th }}$ Ed, Mc Graw Hill, New York, USA pp. 2439-2455.

9. Nokta M (2008) Oral manifestation associated with HIV infection. Curr HIV/AIDS Rep 5: 5-12.

10. Murtiastutik D (2008) Skin disorders in HIV / AIDS patients. Barakbah J, Lumintang H, Martodihardjo S (Eds.), Sexually Transmitted Infections. Surabaya AUP pp. 258-259.

11. Wolff K, Johnson RA (2009) Fitzpatrick's Color Atlas and Synopsis of clinical dermatology. 6th ed. New York : The McGraw-Hill Companies pp. 950

12. Graboyes EM, Allen CT, Chemock RD, Diaz JA (2013) Oral hairy leukoplakia in an-HIV negative patient. Ear Nose Throat J 92(6): 12.

13. Zunt SL, Tomich CE (1990) Oral Hairy Leukoplakia. J Dermatol Surg Oncol 16: 812-881.

14. Miyashita EM, Yang B, Babcock GJ, Thorley-Lawson DA (1997) Identification of the site of Epstein-Barr virus persistence in vivo as a resting B cell. J Virol 71: 4882-4891.

15. Jiang R, Scott RS, Hutt-Fletcher LM (2006) Epstein-Barr virus shed in saliva is high in B-cell tropic glycoprotein gp42. J Virol 80: 7281-7283.
16. Walling DM, Ray AJ, Nichols JE, Flaitz CM, Nichols CM (2007) EpsteinBarr virus infection of Langerhans cell precursors as a mechanism of oral epithelial entry, persistence, and reactivation. J Virol 81: 7249-7268.

17. Palefsky JM, Berline J, Greenspan D, Greenspan JS (2002) Evidence for trafficking of Epstein-Barr virus strains between hairy leukoplakia and peripheral blood lymphocytes. J Gen Virol 83: 317-321.

18. Tugizov S, Herrera R, Veluppillai P, Greenspan J, Greenspan D, et al. (2007) Epstein-Barr virus (EBV) infected monocytes facilitate dissemination of EBV within the oral mucosal epithelium. J Virol 81: 5484-5496.

19. Walling DM, Ling PD, Gordadze AV, Montes-Walters M, Flaitz CM, et al. (2004) Expression of Epstein-Barr virus latent genes in oral epithelium: determinants of the pathogenesis of oral hairy leukoplakia. J Infect Dis 190: 396-399.

20. Cruchley AT, Williams DM, Farthing PM, Lesch CA, Squier CA (1989) Regional variation in Langerhans cell distribution and density in normal human oral mucosa determined using monoclonal antibodies against CD1, HLADR, HLADQ and HLADP. J Oral Pathol Med 18: 510-516.

21. (1993) Classification and diagnostic criteria for oral lesions in HIV infection. Classification and diagnostic criteria for oral lesions in HIV infection. EC-Clearinghouse on Oral Problems Related in HIV Infection and WHO Collaborating Centre on Oral Manifestations of the Immunodeficiency Virus. J Oral Pathol Med 22: 289-291.

22. Graeme JS, Irvine SS, Scott M, Kelleher AD, Marriott DJE, et al. (1997) Strategies of care in managing HIV. In Managing HIV. Australasian Medical Publishing Company Limited, Sydney, USA.

23. (2001) Clinician's Guide to HIV-infected Patients. $3^{\text {rd }}$ Ed. Patton The American Academy of Oral Medicine.

24. (2007) World Health Organization. WHO Case Definitions of HIV for Surveillance and Revised Clinical Staging and Immunological Classification of HIV-Related Disease in Adults and Children p. 15-16.

25. (2014) Center for Disease Control and Prevention. HIV Basic : About HIV/AIDS

26. Diaz-Mitoma F, Ruiz A, Flowerdew G (1990) High levels of Epstein-Barr virus in the oropharynx: a predictor of disease progression in human immunodeficiency virus infection. J Med Virol 31: 69-75.

27. Reginald A, Sivapathasundharam B (2010) Oral hairy leukoplakia : An exfoliative cytology study. Contemp Clin Dent 1(1): 10-13.

28. Schiødt M, Greenspan D, Daniels TE, Greenspan JS (1987) Clinical and histologic spectrum or oral hairy leukoplakia. Oral Surg Oral Med Oral Pathol 64(6): 716-720.

29. Elston DM (2011) Antiviral Drugs. Goldsmith LA, Katz SI, Gilchrest BA Paller AS, Leffell DJ, et al. (Eds.), Fitzpatrick's Dermatology in General Medicine. $8^{\text {th }}$ Ed, McGraw Hill, New York, USA pp. 2787-2796.

30. Resnick L, Herbst JS, Ablashi DV (1988) Regression of oral hairy leukoplakia after orally administered acyclovir therapy. JAMA 259(3): 384-388.

31. Lin P, Torres G, Tyring SK (2003) Changing paradigms in dermatology: antivirals in dermatology. Clin Dermatol 21: 426-446. 
This work is licensed under Creative Commons Attribution 4.0 License

To Submit Your Article Click Here:

Submit Article

DOI: $10.32474 /$ IPDOAJ.2021.05.000214

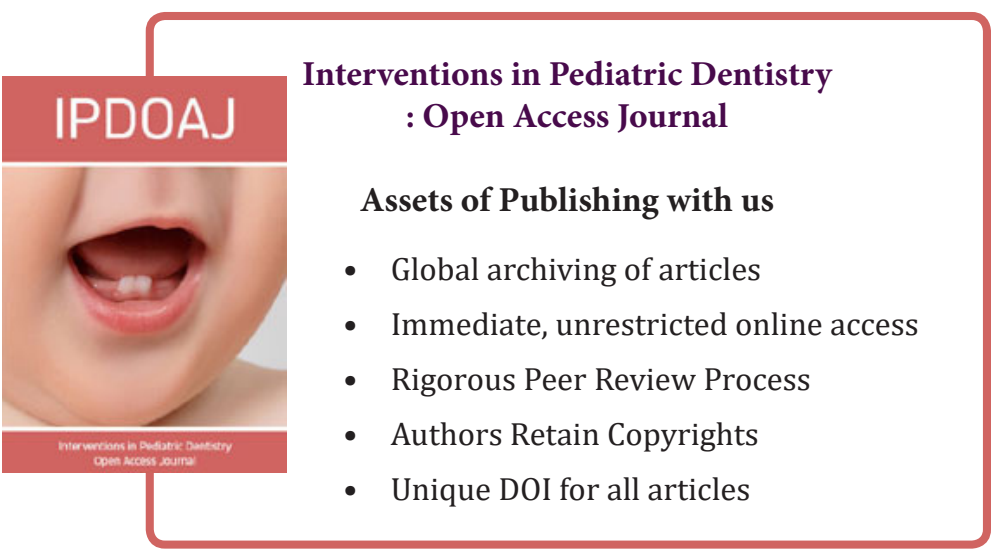

